\title{
INTERVIEW
}

\section{"Art Is Energy": Barbara Hammer Speaks with Sarah Keller about the State of Experimental Cinema after Maya Deren}

B arbara Hammer is a visual artist primarily working in film and video. She was recently honored with retrospectives at the Museum of Modern Art in New York City (2011), the Tate Modern, London (2012), and the Jeu de Paume, Paris (2012). Her work reveals and celebrates marginalized peoples whose stories have not been told, and it engages an audience viscerally and intellectually with the goal of activating them to make social change. Her trilogy of documentary film essays on lesbian and gay history has received numerous awards: Nitrate Kisses (1992), Tender Fictions (1995), History Lessons, (2000). Recent films, A Horse Is Not A Metaphor (2009), Generations (2010), and Maya Deren's Sink (2011) were awarded Teddy Awards for Best Short Film at the Berlin International Film Festival. HAMMER! Making Movies Out of Sex and Life, a book of memoirs and personal film theory, was published by The Feminist Press, City University of New York, and Fearless Frames: The Films of Barbara Hammer at The Tate Modern will be released by Mousse Publishing, Milan, Italy in 2013.

Sarah Keller first became aware of Barbara Hammer's work through her first research into Maya Deren's work, specifically from Hammer's essay in tribute to Deren in Bill Nichols' anthology Maya Deren and the American Avant-Garde (University of California Press, 2001). Since then, she has become a great fan of Hammer's work, and recently invited her to lecture at Colby College, where it has generally been affirmed that during her visit Hammer positively transformed people's lives, not at all unlike the way Deren affected her own audiences. Hammer's films draw on Deren's example in certain ways, but of course they also embrace their own rhythms, their own artistic investments and interests. Hammer and Keller spoke about these issues in New York City in July 2012, and then continued the interview over email in the months following.

Sarah Keller: We're talking about things "after Maya Deren," so I want to ask you about your sense of Deren's legacy for filmmaking. I also want to talk about how you have personally picked up the mantle of her artistic plans or her way of advocating for experimental cinema in general, through networks of distribution, awards, and the Creative Film Foundation, and then talk a little bit about how those kinds of things have influenced you. It might make sense to start with your film Maya Deren's Sink, and the ways that you've taken up some of the things that were dearest to Deren — how you've interacted with those issues recently. 
Barbara Hammer: Maya's films and writing and distribution strategies incredibly influenced me, because I saw that in making work, you could also write about your ideas about work, and then once you'd made it, you could distribute it, or exhibit it, and get it out in the world yourself. Meanwhile, you needed to gain money for your films, so you learned how to write grant applications. Deren got the first Guggenheim in film, which I think is extraordinary, and it was totally right for them to give it to her because film is a fine art the way we artists practice making it. ${ }^{2}$ Also of influence is/was Maya's complete dedication. Her life was really committed to her work, I think, before anything else. That may be the hardest thing to commit to in a world of relationships. The artist has to make the choice for the work, for writing the book, over the family. This is pretty taboo in our society.

SK: Especially for women.

BH: Especially for women, exactly. I see Maya's plans as still viable today. I try to show my work at universities, as you know. Deren's energetic self-distribution showed me a twopronged approach that's often to the artist's advantage. One can distribute her/his films as well as go through an established distribution outlet.

And Maya's many letters to the editor of The Village Voice were important. For example, the column on film she wrote when Jonas Mekas went on vacation and asked her to take over. She had other outlets too, such as magazine articles, and this meant she could write about her own work even if other people didn't (often the general public doesn't understand experimental film). But if you talk about layers of memory represented by images or in Deren's case, "vertical cinema," and explain it, and you're not on a panel with Dylan Thomas_ ${ }^{3}$

SK: Or Arthur Miller.

BH: Or Arthur Miller. Yes. You have a better chance to be understood. And you're challenging your audience, too, because you've given them word concepts as well as image concepts to work with in evaluating your work or experiencing it. Maya's vitality and energy have been remarked upon by so many people. I remember once in the late 70's I was rewinding films, a very physical activity, and I kept repeating a mantra out loud: "Art is Energy, Art is Energy." That was and is my definition of "art."

I think my work, being energetic as it is, reflects my ideas as well. I've always found that every filmmaker has her own personal, interior rhythm that she uses in the editing structure and filming structure, and Deren's was so dance-based, especially when we think of Meshes of the Afternoon.

You make your first film, and you really don't think of yourself in capital letters. You're just burning with your own energy. And then it's made, and Dyketactics becomes a film that people talk about and suddenly you're a filmmaker and you self-reflect. That self-consciousness and reflection cuts down on your spontaneity. And I think it did Deren's after Meshes of the Afternoon. I know, after my '70s films, in the '80s, when I turned to landscape, and I turned to more structural cinema, the exuberance is there but in another fashion. It's not in the freedom of expression with the camera that we find in Meshes, or maybe in Dyketactics.

SK: Well, that's an interesting point, because (as we've talked about) the energy in Meshes is part of Deren's "perfect collaboration" with her then-husband, Alexander Hammid, who used a very mobile camera. He was famous for being able to free up the camera, to walk 
it everywhere, basically doing a kind of steady cam without a steady cam. And in her films after Meshes, Deren doesn't replicate that specific sort of mobility with the camera. But it seems to me that maybe she depends on a more dynamic editing strategy at that point. Would you agree with that?

BH: Dynamic in terms of bringing diverse images together. Meshes is confined to one house and the sidewalk in front. But when she gets to At Land and she uses Buffy Johnson's studio and is out on Long Island, in different locations, both the seaside and the orchard end up butt-ended to each other, and we have a different cinema. She brings us into some kind of global editing in her verticality and geographical discontinuities that become whole through her juxtapositions. Whereas somebody first viewing those films might not feel they're as unified as Meshes. But you're right. She does step out into new editing. Rethinking my earlier statement, Deren does use creative geography in Meshes, too, and steps outside the house and its environment when she traverses diverse landscapes, as in At Land.

SK: That's right. It's there and then continues in Study in Choreography for Camera and Ritual in Transfigured Time...

BH: And Study in Choreography, yes. Talk about editing. That's a masterpiece.

SK: It really is.

BH: And to achieve that jump in air, that use of space... so she really brings in space in the same way she worked with time in Meshes. This is fun, to think about it.

SK: Continuing with these connections, could we talk just a little about homage and Maya Deren's Sink? What are some of the ways that you're paying homage to Deren-or do you feel like there's another element to it besides homage that we should be paying attention to when we're looking at that film?

BH: Maya Deren's Sink is definitely an homage, because the lowly artifact of a bathroom sink is thrown onto the New York streets where people will pick it up, and Anthology Film Archive comes and saves it, and I hear about it and suddenly-I get inspired. As a filmmaker, I never know what's going to come next. I just had this burning desire to first see the sink—and then to project her films back into it.

SK: Why was that? What was it about seeing the sink that was important?

BH: Good question. You know, I've never - there's a person who's in this building who has two artifacts from Maya Deren, she was married to one of Deren's husbands-

SK: Which one?

BH: Teiji Ito. Ilene Ito promised to show me these items, but for various reasons she never fulfilled her promise, and I was never able to see these or put my hands on them. So I think that the sink became a substitute for this desire. When I go to an archive, I want to see the ephemera. It's really interesting. For example, with the Elizabeth Bishop archive I've been visiting at Vassar College, there is her slide projector from the '50s, and I want to see it because I'm shooting a lot of her slides.

I'm not a mystic; it's not that I feel like there's an aura about these objects. I think it's about mortality - my own. I think about what objects of mine will be left. Especially when 


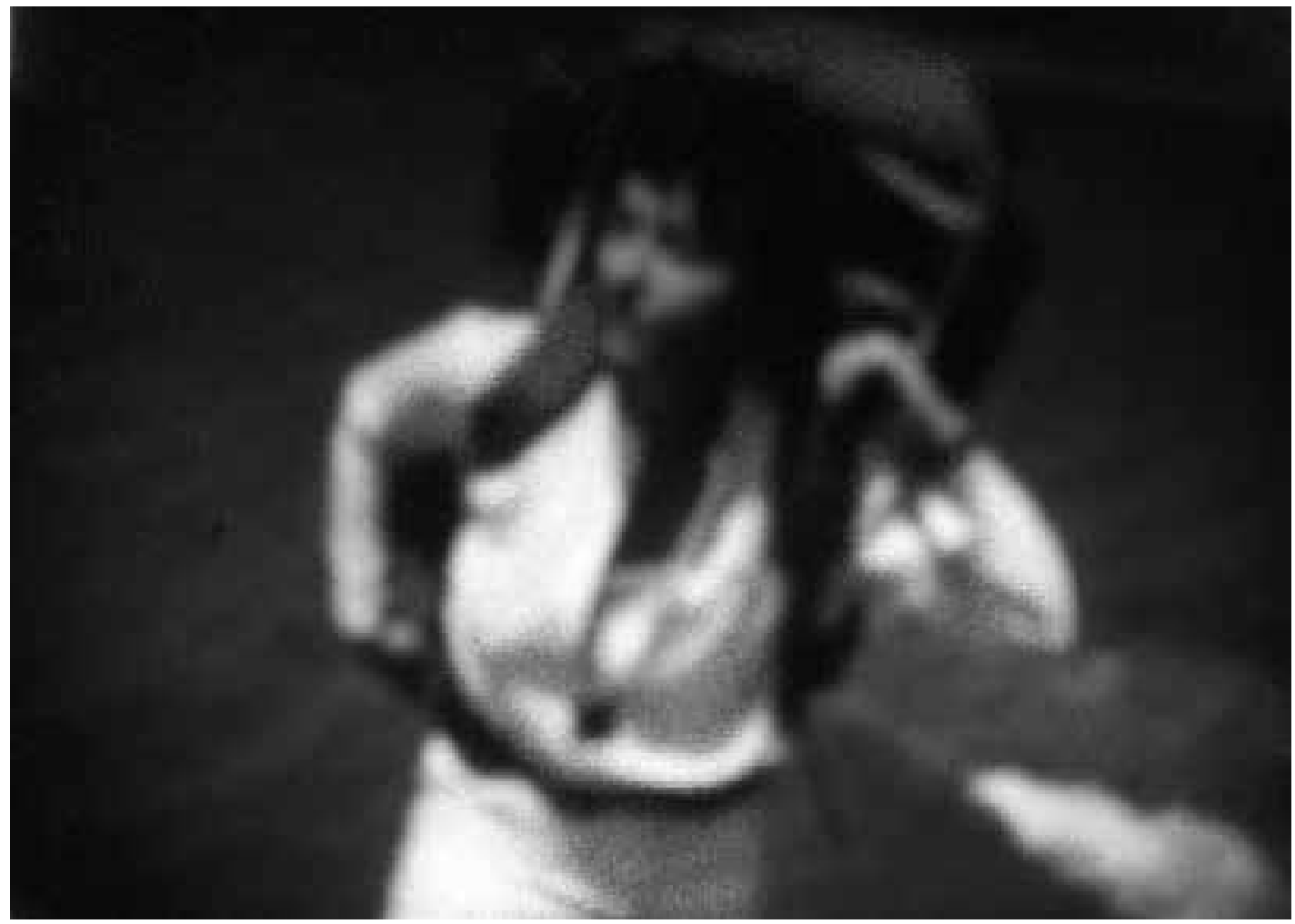

Above: Dream Age (1979), Dir. Barbara Hammer. United States, 12:00 min., 16mm film, color/sound. Courtesy of the artist.

Below: Dyketactics (1974), Dir. Barbara Hammer. United States, 4:00 min., 16mm film, color/sound. Courtesy of the artist.

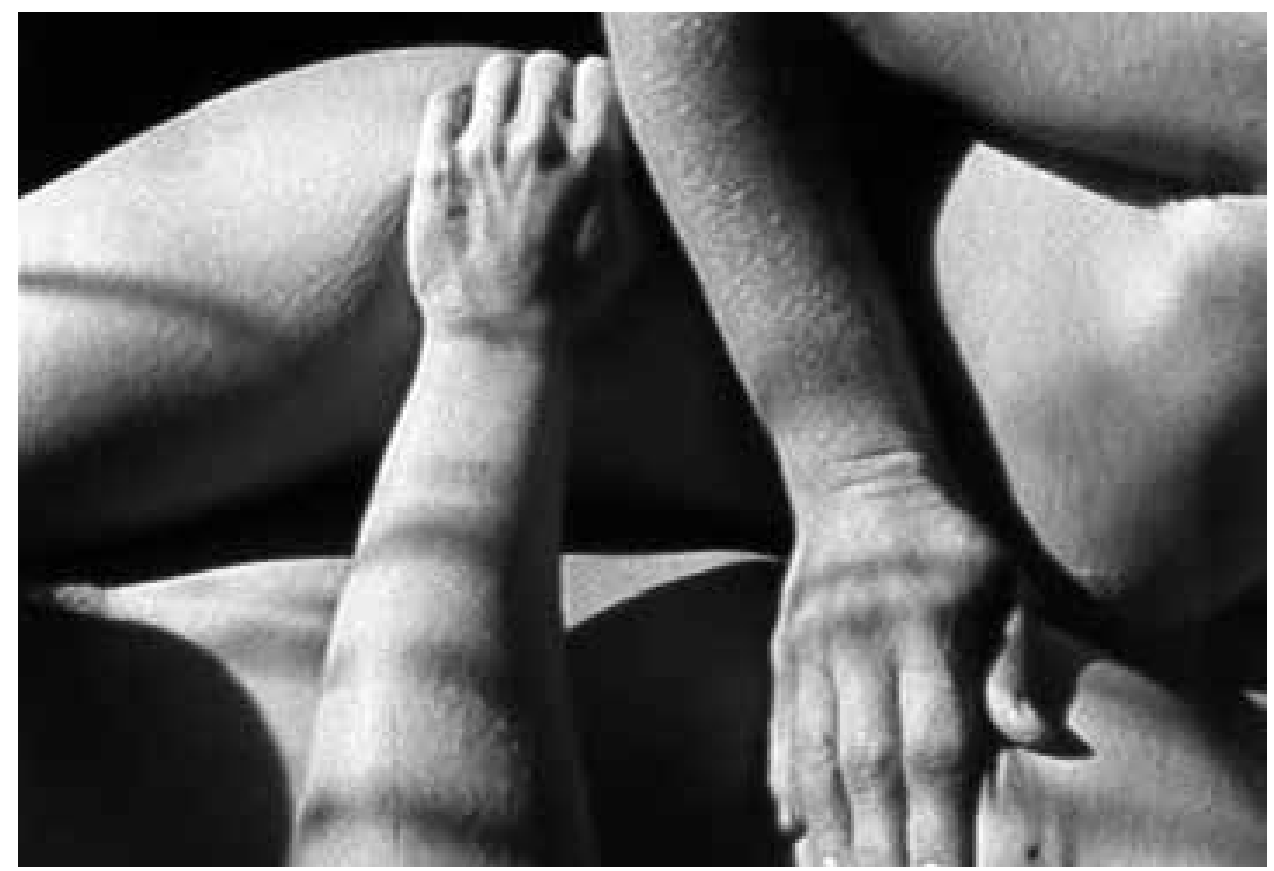




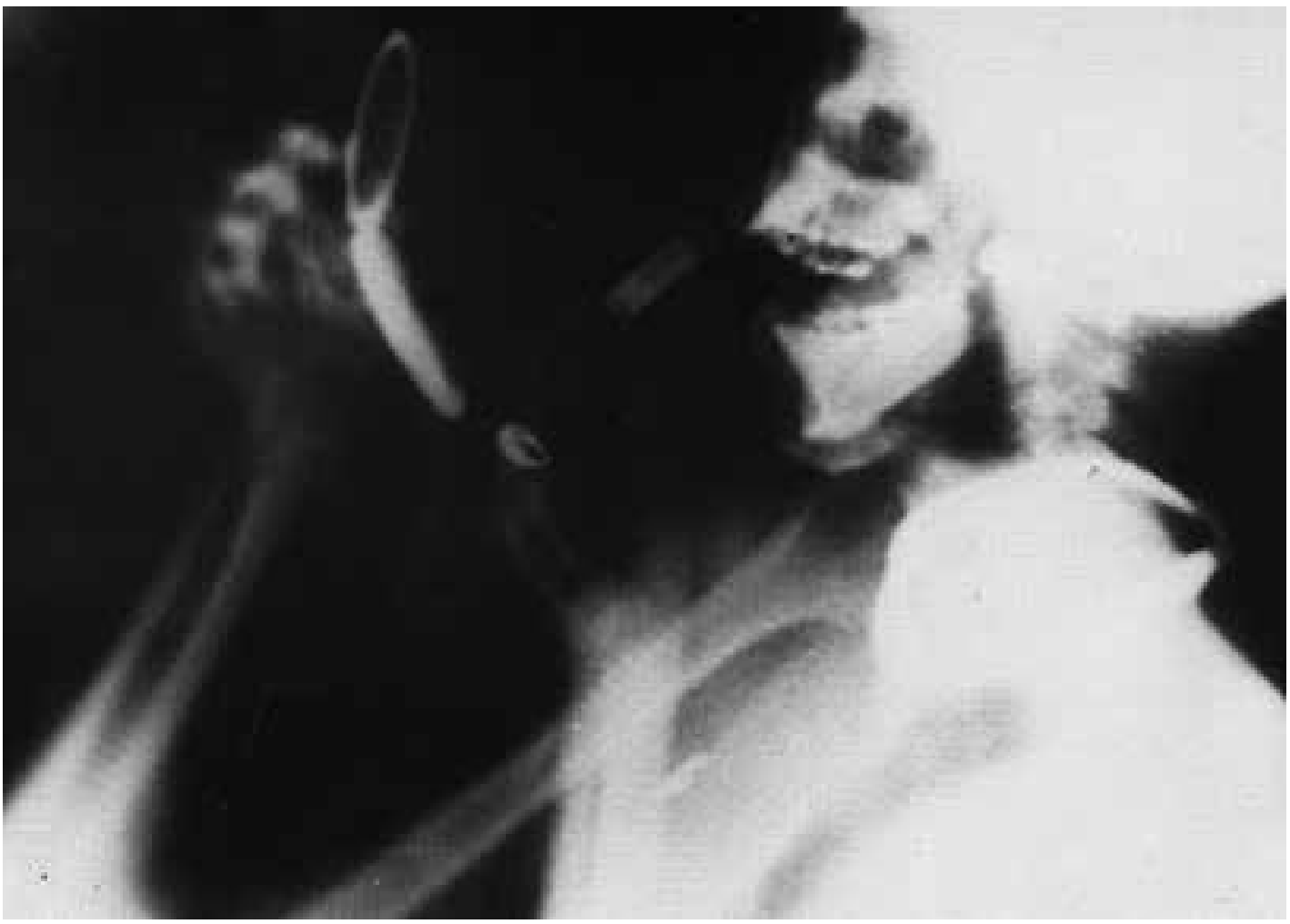

Above: Sanctus (1990), Dir. Barbara Hammer. United States, 19:00 min., 16mm film, color \& B/W, sound by Neil B. Rolnick. Courtesy of the artist.

Below: Home (1978), Dir. Barbara Hammer. United States, 12:00 min., 16mm film, color/sound. Courtesy of the artist.

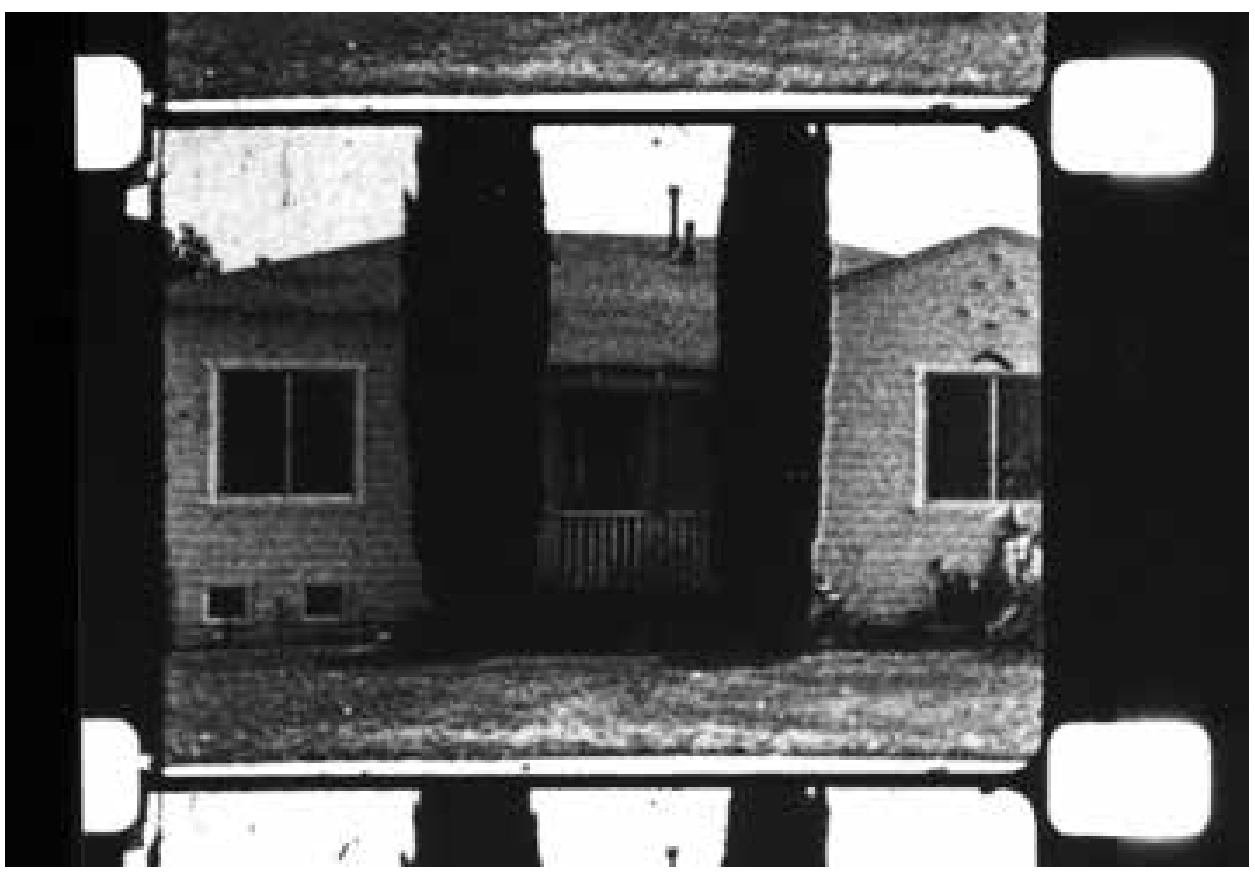


you're going to make a move, a studio move: you've got to get rid of things. And I think: what objects will be left? What should I preserve to benefit or to sell to an archive myself? I think this is one of the reasons I'm doing archive work right now: I'm thinking about my own.

SK: What do you see as the difference between the films you've made becoming artifacts of your creative process versus the other kinds of things that end up in archives?

BH: Well, one thing is: that's what the artist has held onto and passed on. In her archive, there is a nameplate for the house that was one of Elizabeth Bishop's homes: it was very important to her. So you get a sense of the interiority of the artist by looking at the ephemera of the archive. It's something else when we make a leap of judgment to think that the artist has preserved this, not the heir or the executrix of the will. You know Maya Deren's Sink in this case speaks to us of the cultural and economic geography of the time. When I filmed in her former Manhattan home, the house was quite run down. You can see some of the wallpaper that was in one of her films because the plaster has been pulled away due to age. One imagines that she probably didn't have a chance to replace this very ancient sink herself, because in the'50s, there were much better sinks available. This artifact tells you something about her: that her money was going toward films, not into the furniture in her house.

It's curious, but something compels me in my research to know something more than the artworks themselves. The artworks become artifacts, but these other items are also artifacts. Deren, who wrote so much, reminds us that letters are objects, paper sheets, and there must be a lot that was never published. It must be a very rich archive. In answering your question, I notice I've spoken about Deren's archive, not my own, because it's easier.

SK: And who knows, as you say, which of these articles Deren wanted to have preservedin some cases, she had catalogued her own things, so it seemed like it was already being archived. But other things-parking tickets, for example-probably not. So it makes me wonder about an artist's legacy and how we read that legacy according to these material traces of her presence while she was here.

BH: That's the artistic practice of being an academic or a biographer. I mean if we look at biographical and archival studies as being not about truth but about imagination, and we give the maker of that work - you, in terms of your book on Maya Deren - the embrace of being able to be creative in your work - to use your imagination, to use hypotheses - then we have a more vital production in the end. Because there's no way to know the truthabsolutely no way to do anything but regard the solid "facts," i.e., leftovers. And the truth is-we know there's no truth.

SK: Right. If we get to the truth, it's still subjective; it still is subject to change.

BH: I'd also like to say something else about her homes.

SK: Please do.

BH: The home-or the studio, if one is lucky-is where the artist works and creates. And that kind of structure, or space, most of it being rectangular and small for us artists I think, has a lot to do with the work we make. If Maya Deren lived in the woods as a wild child with 
a video camera, with multiple hours of recording devices, I think we'd have a different kind of film. And I think that Meshes and Ritual are really home-based works. Meshes was all shot in her home. A lot of Ritual in Transfigured Time was shot in her Morton Street home and some of Study for Choreography for Camera was too. The interior structure of the home means the artifacts in the home are visible as images on the screen for us to see, even if we can't handle them. If an artist is working in space-time relationships, the space that she lived in and worked in seems to me a very interesting primary focus of what occurs in the filming itself.

Then there's just the personal desire. Desire is — as it has been defined, I think —what you can't have. Who can go into the homes of Maya Deren? Well, at first I can't, but then I want to, and I find a way. I wanted to go into her homes especially after I found out that they were still here-they hadn't been destroyed. And I love challenges. Those homes should be museums. They should be preserved as part of the archive. They shouldn't be destroyed nor ignoredwe should at least have a plaque on her homes to memorialize her.

SK: I agree.

BH: But that requires the owner of the building to admire Maya Deren, which isn't the case in New York.

SK: Tell me about the kinds of traces of home in your own films.

BH: Well, I made a film called Home, of 9536 Felton Avenue in Inglewood, California, where my first memories come from. I moved, or was moved there, when I was about maybe three months of age, and I grew up through twelve in that home. I remembered the home from the size that I was. It was very interesting to me to go back and visit as an adult and notice the way the grasses grew around a particular tree and whether the tree was even still there. And the dirt, and the driveway being those two cement tracks with grass growing in between, something different than our driveways today, which are solidly paved. It was fulfilling a desire to recall, to remember, to explore that house with a moving camera, as I did, and then to abstract it through using infrared film so that the leaves are red, rather than green. Home gave me a way to re-experience my own life as a subjective process, but isn't that what we are always doing?

SK: That transformative use of infrared is really interesting. In fact, it sounds a lot like the widow-into-bride moment of Ritual in Transfigured Time. Do you think there are aspects of Deren's film style that have found their way into your own creative imagination?

BH: I immediately think of a film of mine that is very rarely viewed; it's called Dream Age. The last image of that film is me with a backpack, walking into the ocean-actually into the San Francisco Bay, submerging myself. It was my attempt to mature. The characters in the film are all women with white hair, and I don't yet have white hair. In a ritual, on a salt mound, they paint my hair white. A ritual is a repeated activity, and eventually the repeated activity is that my hair is painted completely white. I wanted to hurry along the process of aging. I wanted to know more, to be more critical and reflective-my idea of what age can bring.

SK: Deren worked on several projects that are intimately tied to rituals, too, especially her monumental project in Haiti, for which she planned to use Voudoun ritual dances as the centerpiece. Do you have thoughts on why she would have had trouble working with this 
material—ritual, sacred dances_even while she didn't have trouble filming non-sacred, camera-generated dances?

BH: The most exciting chapter of Divine Horsemen was the one where Deren is mounted by Erzulie during a Voudoun ritual. I cannot comprehend how she could make a film, or part of a film, about this experience since there is a loss of consciousness as we know it -or, so it seems to me-during possession. Perhaps this is why Deren never edited, nor even began to edit, her vast cans of footage. And when Joseph Campbell told her to write a book instead, telling her that she knew more about Voudoun than any anthropologist, she proceeded without hesitation. I wonder about that. Now I want to go back and see what she did in words that she didn't do in film.

SK: Do you think your allusions to Deren's work were conscious? Do you feel you learned some of your filmmaking from Maya Deren, or did you sort of unconsciously absorb some of her aesthetic and use it - maybe especially at the beginning of your career?

BH: I definitely used consciously Deren's line in the film where I'm talking about time being circular and not linear. ${ }^{4}$ take the key out of my mouth, and that's in direct reference to Deren's key that opens the door to her psyche, her house. My key starts my BMW motorcycle: my dyke bike. On the motorcycle is the squash, the pumpkin I've found in the field. I open the squash: what's in it, but a knife. We think of the knife on the bed in Meshes of the Afternoon and I feel that the knife for both of us was a means of protecting our burgeoning feminine, constructed, yes, but there, burgeoning feminine sensibilities. It's about women experiencing time differently.

And then there's the gun. There's no gun in Deren, but the knife has the same sense of violence about it that the gun has. They are both seen as an instrument of power. Deren had the bed, a passive place, where she lay, and even the chair, the armchair, again displays her restful passivity. If anything, I'm changing Deren into a motorcycle dyke. Or a woman of the women's movement of the 1970s, which happened at the same time I was becoming a filmmaker. Finally, after thinking through the film I believe there are both conscious and unconscious projections in the work. I don't think embracing pumpkins and running through a pumpkin field was Deren-influenced, but the projection on the body might have been because there is, in Deren, there's that-those eyes blinking. I'm not sure if that is a projection on her or literally her eyes blinking. In any case, there is the projection in the mirror, and the breaking of the mirror, of Hammid's face. And in I Was/I Am, I'm breaking a glass bell jar that was put over my head-with a hammer. There are a lot of influences including Sylvia Plath and her novel The Bell Jar.

SK: Let me ask you some more about influences, for example in collaborations with others. Deren worked with dancers, including Talley Beatty, Frank Westbrook, and Rita Christiana, and she used other people who are not dancers, including Anaïs Nin, Gore Vidal, and anyone she could find to do the party sequence in Ritual in Transfigured Time where she needed people to move in a choreographed way. But she had problems when she began to enlist the aid of thirty people because it's difficult to get thirty people to agree to meet for free at a certain time and do crazy things for twelve hours. I'm wondering about your own practice - in many of your films you're using your own figure, which Deren also did. Is 
that in part to obviate the need to depend on others, or is it more of a personal expression of your own subjectivity or something else? Or is it for other reasons entirely?

BH: I have worked in collaboration going all the way back to Dyketactics, which for that film meant gathering a group of women and taking them to the country for a weekend, along with sync sound cameras, back-up cameras, Nagra reel-to-reel tape recorders, and a full crew of women to shoot and record. I provided food for them and camping places to sleep, and spontaneously directed rituals in nature. Women are jumping through the leaves, embracing trees, maybe six or seven within the film frame at a time. My approach was to take what I could get. Give a general direction, and then as people are performing what you've asked for, you can find your way to film it. Or accept it. Some of the best images are the unpracticed, unrehearsed, undirected ones such as a little child meandering across the screen to get her hair brushed, or women sitting casually by the streamside, not in performance mode, not posing. But to think of Deren managing thirty people in the dance scene of Ritual in Transfigured Time, you know that would be very difficult, especially knowing how exact she was. It's a different aesthetic altogether having to do with control or letting the control go.

SK: I want to ask you more about your sense of choreography, dance, and rhythm.

BH: I have been thinking about Maya Deren in terms of contemporary dance today, and I've been thinking about Yvonne Rainer and the Judson school and the very minimal approach Rainer and others, but especially Rainer, took toward what dance is and the way dance was redefined. I think some of Deren's work is very early structural, minimalist work. The way one walks, the way one puts the foot down, the way one crawls through a tree trunk on the beach. You know, very planned and minimal.

The definition of dance is like the definition of art: whatever the dancer or artist says is "dance" is or "art," is. I only know Rainer's work from the Judson Dance Theater period, that minimal period where she struck a new note for dance by walking across the dance floor or by walking across the dance floor bouncing a ball. Maya Deren takes a step on the stairs of the North Hollywood cottage and freezes; then another step and position and freezes; another and another: minimal. But who is dancing? Maya or the cinematographer cameraman, her husband at the time, Alexander Hammid? Who was dancing and who was directing, and could the dancer dance without direction?

Similarly, Bekka Lindstrom, who amazingly had made her own film using Deren motifs when a student at NYU film school, was asking me while acting in Maya Deren's Sink: "What is Voudoun ritual dance?"What did I know? I had seen Divine Horsemen, I had my own idea of what the movement would look like if the person dancing lost a sense of self in merging with a stronger force-for me, that stronger force could even be gravity. I just started to shake and move, allowing my body to be pulled towards the ground, closing my eyes, and then Bekka took over and found her way, the way you see in the film.

SK: This reminds me of the way you were talking about the rhythm of natural movement... would you say that this kind of rhythm is important to your films? Do you think you use it in a similar or different way from how it is used by Deren?

BH: Rhythm is the basis of my life, the way I move, the way I edit. I believe each one of us has a different rhythm and that if we are based in a movement art form our best work can 
be done by corresponding and dialoguing with our inner rhythm. Deren had her rhythm, I have mine, you have yours. It is the rhythm of the coursing of blood through our body; the breath through our nostrils and lungs; the musculature, structure, and movement dictated by brain rhythm. Last week I took a class in the Martha Graham studio where the Merce Cunningham studio had been. Even though we were assigned contraction/expansion à la Graham, I could not help but diverge and add my own beats, twirls, skips and hops. It is very hard to follow a standard routine as my internal rhythm demands variation. I have to admit I was a little pleased with the instructor who asked if I were a choreographer. Deren was a choreographer of cinema, and although formally untrained, I would hope I may have followed a few of her leaps and bounds, aka, the Choreography of a Dancer.

SK: When you mention minimalist movement as Deren's dance aesthetic, it makes me think of one of my favorites of your films: Sanctus. I admire it so much in part because it so beautifully depicts the motion of the human body but in a completely minimalist form. Would you relate that film to the kinds of dance movement you are talking about?

BH: It's strange but Talley Beatty's ribs come to mind. The ribs, the staircase, the layers of stratification of the skeleton pushing against the skin as minimal, although we like to think of ourselves as more than minimal. The footstep geography expanded, one time on the grass, one at the seashore, followed by a footstep on concrete, and the final one on the carpet of the room in which you commit suicide. Thank you, Maya Deren, for expanding our space as well as our time with four shots. Nothing could be more minimal than that.

SK: And thank you, Barbara, for your elucidation of Maya Deren's work in relation to your own, and for carrying forward the same spirit of exuberance and panache in your creative film work!

\section{Notes}

1. Hammer's Maya Deren's Sink (2011) addresses the artifacts of Deren's life and film work through a creative documentary approach, fixating on an abandoned sink from Deren's Greenwich Village apartment as well as Deren's writings and persona.

2. Maya Deren was awarded the first Guggenheim foundation grant for "creative work in motion pictures" in 1946.

3. Deren participated in a Cinema 16 roundtable discussion: "Poetry and the Film: A Symposium," along with Arthur Miller, Dylan Thomas, Willard Maas, and Parker Tyler, in October of 1953. A transcript of the discussion is reprinted in P. Adams Sitney, ed., Film Culture Reader. Miller and Thomas disparage Deren's remarks about cinema that is "vertical" (one that "probes the ramifications of the moment, and is concerned with its quality and its depth," in Deren's words) versus "horizontal" ("one action leading to another.") See Sitney 173-174, 184.

4. See Hammer, I Was / I Am. 


\section{References}

Deren, Maya. Divine Horsemen: The Living Gods of Haiti. Kingston, NY: Documentext, 2004.

Fearless Frames: The Films of Barbara Hammer at The Tate Modern. Milan: Mousse Publishing, forthcoming 2013. Hammer, Barbara. HAMMER! Making Movies Out of Sex and Life. New York: The Feminist Press, City University of New York, 2010.

Nichols, Bill, ed. Maya Deren and the American Avant-Garde. Berkeley: University of California Press, 2001.

"Poetry and Film: A Symposium with Maya Deren, Arthur Miller, Dylan Thomas, Parker Tyler. Chairman, Willard Maas. Organized by Amos Vogel." In Film Culture Reader, edited by P. Adams Sitney, 171-186. New York: Cooper Square Press, 1970.

\section{Media}

At Land (1944). Dir. Maya Deren. 16mm film, 14:00 min., B\&W/Silent.

Dream Age (1979). Dir. Barbara Hammer. 16mm film, 12:00 min., Color/Sound.

Dyketactics (1979). Dir. Barbara Hammer. 16mm film, 4:00 min., Color/Sound.

Generations (2010). Dir. Barbara Hammer, with Gina Carducci. 16mm film, 30:00 min., Color/B\&W/Sound.

History Lessons (2000). Dir. Barbara Hammer. 16mm film, 66:00 min., color/sound.

Home (1978). Dir. Barbara Hammer. 16mm film, 12:00 min., Color/Sound.

A Horse Is Not A Metaphor (2009). Dir. Barbara Hammer. DVD, 30:00 min., Color/B\&W/Sound by Meredith Monk. I Was / I Am (1972).Dir. Barbara Hammer. 16 mm, B\&W, sound.

Maya Deren's Sink (2011). Dir. Barbara Hammer. HD, 29:00 min., Color/B\&W/Sound.

Meshes of the Afternoon (1943). Dir. Maya Deren and Alexander Hammid. 16mm film, B\&W. Sound by Teiji Ito added 1959

Nitrate Kisses (1992). Dir. Barbara Hammer. 16 mm film, 67:00 min., B\&W/sound.

Ritual in Transfigured Time (1946). Dir. Maya Deren. 16mm film, 15:00 min., B\&W/Silent.

Sanctus (1990). Dir. Barbara Hammer. 16mm film, 19:00 min. Color \& B/W, Sound by Neil B. Rolnick.

Study in Choreography for Camera (1945). Dir. Maya Deren. 16mm film, 3:00 min., B\&W/Silent

Tender Fictions (1995). Dir. Barbara Hammer. 16mm film, 58:00 min., color/sound. 